
\title{
28 Research Suare \\ Prevalence and significance of potential drug-drug interactions among cancer patients receiving chemotherapy
}

Mohammad Ismail ( $\square$ ismailrph@uop.edu.pk)

University of Peshawar https://orcid.org/0000-0001-7227-3399

\section{Sehrash Khan}

University of Peshawar

\section{Fahadullah Khan}

University of Peshawar

\section{Sidra Noor}

University of Peshawar

\section{Hira Sajid}

University of Peshawar

\section{Shazia Yar}

University of Peshawar

Irum Rasheed

University of Peshawar

\section{Research article}

Keywords: Patient safety, cancer, supportive therapy, potential drug-drug interactions, polypharmacy.

Posted Date: April 1st, 2020

DOI: https://doi.org/10.21203/rs.2.22832/v2

License: (우 (i) This work is licensed under a Creative Commons Attribution 4.0 International License. Read Full License

Version of Record: A version of this preprint was published at BMC Cancer on April 19th, 2020. See the published version at https://doi.org/10.1186/s12885-020-06855-9. 


\section{Abstract}

Background: Cancer patients often receive multiple drugs to maximize their therapeutic benefit, treat comorbidities and counter the adverse effects of chemotherapy. Concomitant administration of multiple drugs increases the risk of drug interactions leading to compromised therapeutic efficacy or safety of therapy. The purpose of this study was to identify the prevalence, levels and predictors of potential drug-drug interactions (pDDIs) among cancer patients. Methods: Six hundred and seventy-eight patients receiving chemotherapy from two tertiary care hospitals were included in this cross-sectional study. Patient medication profiles were screened for pDDIs using the Micromedex ${ }^{\circledR}$ database. Logistic regression analysis was performed to identify the predictors of pDDIs. Results: The overall prevalence of pDDIs was $78 \%$, majority of patients had 1-2 pDDIs (39.2\%). A total of 1843 pDDIs were detected. Major-pDDIs were most frequent (67.3\%) whereas, a significant association of pDDIs was found between $>7$ all prescribed drugs $(p<0.001)$ and $\geq 3$ anti-cancer drugs $(p$ $<0.001$ ). Potential adverse outcomes of these interactions include reduced therapeutic effectiveness, QT interval prolongation, tendon rupture, bone marrow suppression and neurotoxicity. Conclusions: Major finding of this study is the high prevalence of pDDls signifying the need of strict patient monitoring for pDDIs among cancer patients. Patients at higher risk to pDDIs include those prescribed with $>7$ any types of drugs or $\geq 3$ anticancer drugs. Moreover, list of most frequently identified major and moderate interactions will aid health care professional in timely identification and prevention of pDDIs.

\section{Background}

The global cancer burden is on the rise due to increased prevalence of risk factors such as smoking, environmental pollution, obesity, unhealthy diet, physical inactivity, infections (hepatitis, helicobacter pylori and human papilloma virus) and use of oral contraceptives [1-4]. The Global burden of cancer (GLOBOCAN) 2012, reported an estimated 14.1 million new cases of cancer, which is anticipated to rise by $70 \%$ over the next 20 years $[2,3]$. Cancer is equally prevalent around the world $[3,5]$, however differences in the pattern of cancer and its subsequent therapy exist from region to region [5]. The overall survival of cancer is high in developed countries due to timely and easy access to standard health care facilities $[1,2,6,7]$.

The use of cytotoxic agents is inevitable for the cure of cancer despite the availability of a number of other alternatives such as surgery and radiation $[8,9]$. The main aim of chemotherapy is to cure cancer, extend life years and improve the overall quality of life $[7,8]$. Cytotoxic agents are often administered in combination containing two or more cytotoxic drugs as multiple drug regimens along with other medicines to achieve maximum therapeutic benefit and counter the adverse effects of chemotherapy or to treat other co-illnesses [10, 11]. However, interpatient variability is frequently observed especially with oral cytotoxic agents due to drug interactions as a result of polypharmacy $[12,13]$.

Drug-drug interactions (DDIs) are drug combinations that may result in therapeutic failure or potentially serious adverse events than from solitary administration [14-18]. An estimated $2 \%$ of hospital admissions are due to adverse effects caused by DDIs $[19,20]$ and approximately $4 \%$ of the cancer patients die because of adverse effects caused by drug interactions [21] however, DDIs are often predictable and preventable [22, 23]. Advance age, prolonged hospital stay and increased number of prescribed medicines are strong predictors of DDIs [2427]. The risk of DDIs and its associated adverse events are higher in cancer patients as they frequently receive 
multiple drugs concomitantly $[17,25]$. Moreover, there has been a recent increase in the availability and use of anticancer agents because of favorable therapeutic outcome and cost effectiveness [12, 28].

DDIs among cancer patients have been well studied in developed countries [20, 24, 26-29]. However, such studies have been poorly addressed in developing countries like Pakistan. There are a few studies which have their own scope and limitations such as involving only QT prolonging DDIs [30], small sample size and different drug interactions screening tool [31], and primarily focused on medication safety [32]. Further, we cannot generalize the findings of developed countries to the developing countries because of variations in drug prescribing pattern, utilization of anticancer drugs, pattern of cancers, drug interactions screening before prescribing, and non-availability of standard healthcare services.

DDIs involving anticancer drugs are a major concern in oncology practice due to their potential to cause severe adverse effects $[1,28,33,34]$. Moreover, knowledge about the most common interacting drugs used in cancer patients and identification of predictors of pDDIs are essential to reduce avoidable drug-related problems and increase the efficacy and compliance of chemotherapy $[14,17]$. Additionally, this study will be helpful for the promotion of rational drug use and for the prevention and management of drug interactions leading to improved therapeutic outcome and patients' quality of life [34,35]. Therefore, the study aimed to identify the prevalence, levels, predictors and potential adverse outcome of pDDIs among cancer patients receiving chemotherapy.

\section{Methods}

\section{Study settings and design}

A cross-sectional study was performed in two tertiary care hospitals of Peshawar, Khyber Pakhtunkhwa, Pakistan: Hayatabad Medical Complex (HMC) and Northwest General Hospital and Research Center (NWGH \& $\mathrm{RC})$. $\mathrm{HMC}$ is a public sector tertiary care teaching hospital whereas, NWGH \& RC is a private sector hospital.

\section{Selection criteria}

Patients of any age and either gender diagnosed with any type of cancer and treated with anticancer agents (either intravenous and/ or oral) were included in this study. Whereas, patient profiles were excluded if the required information were lacking.

\section{Data collection and screening for pDDls}

Data regarding patient's demographic, symptoms, laboratory results and prescribed medications were collected after acquiring written permission from the administration of respective hospitals.

Micromedex Drug-Reax® (Truven Health Analytics, Greenwood Village, Colorado, USA) was used for the screening of patients' medication profile for pDDIs [36]. We select this software because it has got highest sensitivity and specificity score $[37,38]$. Further, it has got sensitivity score of $70 \%$ in identifying drug interactions involving oral anticancer drugs [39]. According to the description of this database, all detected interactions were categorized on the basis of severity-levels and documentation-levels [36]. All available lab values were reviewed to identify abnormal results. 


\section{Statistical analysis}

In statistical analysis, quantitative data were presented as frequencies and percentages. Logistic regression analysis was applied in order to identify association of pDDIs presence with patients' gender, age, prescribed medications, hospitalization status, cancer type, presence of metastasis, treatment type and treatment intent. For each predictor odds ratio (OR) a $95 \%$ confidence intervals (Cls) was determined by performing univariate logistic regression analysis. For variables with significant univariate $\mathrm{p}$-values multivariate analysis was performed. In this study p-value of 0.05 or less was considered significant. SPSS version- 23 was used for statistical analysis.

\section{Results}

\section{Patients characteristics}

Out of total 678 patients, $358(52.8 \%)$ were male and $320(47.2 \%)$ were female. Majority of patients were in the age range of $41-60$ years (29.5\%) followed by $21-40$ years (26.4\%). The use of 7-9 drugs (37.3\%) and 10-12 drugs $(29.4 \%)$ were most frequent. Whereas, majority of patients $(81.9 \%)$ were prescribed $\geq 2$ anti-cancer drugs and $\geq 4$ supportive drugs ( $87.6 \%)$ as presented in Table 1 .

\section{Cancer profile and treatment of study subjects}

Table 2 illustrates cancer profile and its treatment for study subjects. Solid malignancies were most frequent among the study participants (53.1\%) as compared with hematologic malignancies (46.9\%). Metastasis was seen in $112(16.5 \%)$ patients whereas $620(91.4 \%)$ patients were receiving curative treatment. Moreover, the use of cytotoxic agents $(74.9 \%)$ and combination therapy $(24 \%)$ were common while hormonal or monoclonal agents were rarely prescribed. The most frequent solid malignancies include gastrointestinal cancer (13.1\%), breast cancer (9.4\%), gynecological cancer (6.9\%), musculoskeletal cancer $(6.2 \%)$ and genitourinary cancer (6\%). Likewise, the most frequent hematological malignancies include acute lymphoblastic leukemia (18.7\%), non-Hodgkin lymphoma (17.3\%), and acute myelogenous leukemia (4.1\%).

\section{Prevalence of pDDIs}

Figure 1 indicates that 529 patients were exposed to at least one pDDI (overall prevalence $=78 \%$ ). Majority of patients had 1-2 pDDIs (266), 5-6 pDDIs (100) and 3-4 pDDIs (93).

\section{Levels of pDDls}

Overall, 1843 pDDIs were detected, of which, 1240 (67.3\%) were of major and 507 (27.5\%) were of moderate severity while contraindicated pDDIs were least frequent accounting for $25(1.4 \%)$ pDDIs. The documentary evidence of majority of pDDIs were fair (66.4\%) and good (23.8\%) (Figure 2).

\section{Predictors of pDDIs}

Table 3 demonstrates the results of univariate and multivariate logistic regression analysis for exposure to pDDIs. Results of univariate logistic regression analysis indicates a significant relation of pDDIs with all prescribed drugs, anticancer drugs, supportive care drugs, hospitalization, type of cancer and type of cancer 
treatment. The odds of pDDIs are 3.6 times with $>7$ all prescribed drugs $(p<0.001), 4.7$ times with $\geq 3$ anticancer drugs $(p<0.001), 1.9$ times with $>3$ supportive care drugs $(p=0.001), 1.8$ times with hospitalization $(p=$ $0.004), 2.1$ times with combination treatment $(p=0.003)$ and 0.4 times with solid malignancy $(p<0.001)$. Whereas, the risk is insignificant for gender, age, presence of metastasis and treatment intent.

Likewise, the results of multivariate logistic regression analysis show a significant relation of pDDIs with the presence of $>7$ all prescribed drugs $(p<0.001)$ and $\geq 3$ anti-cancer drugs $(p<0.001)$. Whereas, the association of pDDIs with supportive care drugs $(p=0.2)$, hospitalization $(p=0.3)$, type of cancer $(p=0.2)$ and type of treatment $(p=0.3)$ are insignificant.

\section{Abnormal symptoms and laboratory results}

Table 4 presents the abnormal biochemical results and symptoms among study subjects. Hematological tests show reduced hemoglobin in majority of patients $(58.7 \%)$ whereas, $118(17.4 \%)$ patients were reported with reduced red blood cell count. Similarly, leukocytopenia was observed in $96(14.2 \%)$ patients with decreased neutrophil count in $70(10.3 \%)$ patients, decreased lymphocytes in $149(21.9 \%)$ patients and reduced eosinophils and monocytes in $47(6.9 \%)$ and $372(54.9 \%)$ patients, respectively. Abnormal high serum creatinine was reported in $26(3.8 \%)$ patients and $12(1.8 \%)$ patients had elevated bilirubin level. While among the liver function tests, 121 (17.8\%) patients had elevated ALT levels and 106 (15.6\%) patients had elevated alkaline phosphatase level. Whereas, the most frequently observed symptoms among the study participants include fever $(12.1 \%)$, generalized body ache $(9.3 \%)$, nausea \& vomiting $(4.7 \%)$, abdominal pain $(4.1 \%)$ and cough (3.8\%).

\section{Wide spread interacting drug combinations}

Most frequently detected pDDIs are enlisted in Table 5 along with their severity, documentation levels and potential adverse outcomes. Reduced therapeutic effectiveness, QT interval prolongation, drug toxicity such as tendon rupture, bone marrow suppression, seizures, serotonin syndrome, neurotoxicity and cardiomyopathy were the potential adverse outcomes of these interactions. Potential drug-drug interactions involving anticancer agents are enlisted in additional table 1.

\section{Discussion}

This study presents the frequency, severity and predictors for pDDIs and list of most frequent pDDIs among cancer patients undergoing chemotherapy. An overall $78 \%$ prevalence of pDDIs is higher in comparison with other studies conducted in oncology setting. A study from Iran reported $62.8 \%$ prevalence of pDDIs in patients with hematological malignancy [40]. Another study from Netherland reported a prevalence rate of $46 \%$ among patients using oral anticancer drugs [41]. Whereas, a study from the United States of America reported $40 \%$ prevalence rate of pDDIs [29]. Similarly, the prevalence rate of present study is higher in comparison with studies from other specialties such as internal medicine (52.8\%) [25], psychiatry (64.8\%) [42], pediatrics (25.8\%) [43] and pulmonology (45\%) [44]. Such widespread variability in prevalence may be attributed to differences in study designs, inclusion and exclusion criteria, study population \& their characteristics, study settings, presence or absence of clinical pharmacy services, prescribing pattern, drugs involving, and high sensitivity of drug 
interactions screening databases/sources. The high prevalence of pDDIs identified in our study demands thoughtfulness regarding the issue of pDDIs in cancer patients receiving chemotherapy.

Levels of pDDIs are imperative for healthcare professionals to evaluate their potential clinical significance and rationalize the patients' treatment. All interactions are not equally harmful, therefore, classification of the identified interactions into different levels helps in proper management of these interactions. The more frequent occurrence of major pDDIs is an important finding of this study, necessitating the need of strict monitoring of patients as these interactions carry higher potential for causing life threatening adverse reactions. A study reported similar results in hematological malignancies [40] however, in majority of studies moderate pDDIs are more frequent $[41,45,46]$.

The use of polypharmacy is prevalent among cancer patients. The significant association of $>7$ prescribed drugs and $\geq 3$ anti-cancer drugs with pDDIs in present study are coherent with other studies both in oncology setting and other specialties $[17,22,27,47]$. The presence of polypharmacy in cancer patients demands the screening of prescribed medications for timely prediction and prevention or minimization of any unwanted negative consequences as polypharmacy is inevitable among cancer patients. The univariate analysis estimated a significant association of pDDIs with hospitalized patients, combination chemotherapy and patients having solid malignancy however, they were insignificant in multivariate analysis. Moreover, like other studies age, gender, metastasis and treatment intent had insignificant association with pDDIs $[17,34,45]$ however, few studies have reported a significant association of pDDIs with gender, age and type of cancer [28, $34,48,49]$.

List of most frequent pDDIs particularly those of contraindicated, major and moderate severity are of utmost importance for health care providers. It can aid in the selective screening of pDDIs by overburdened health care professionals. Such information is needed for health care professionals to estimate the risk in specific patients and guide their therapeutic decision making [8]. Patients at risk of these interactions may be given special attention and their therapy may be closely monitored for any potential adverse effect.

There are a few potential limitations of this study. Although, this work explored pharmacoepidemiology of pDDIs in cancer patients, the exact extent of patient suffering due to these interactions were not studied. The study was conducted only in two hospitals, which is the second point which may limit the generalizability of this study. Moreover, only one drug interactions screening database (Micromedex Drug-Reax ${ }^{\circledR}$ ) was used for the identification of pDDIs, however, other sources are also available which may not necessarily give the same results. Further, we have only included hospitalized cancer patients receiving intravenous and/ or oral anticancer agents. In hospital settings, mostly intravenous anticancer therapy is provided. We don't include cancer patients treated in homebased care settings which could provide a different DDIs pattern due to frequent use of oral anticancer agents.

\section{Conclusions}

This study points out a high prevalence of pDDIs among cancer patients treated with anti-cancer agents. Majority of interactions were of major and moderate severity. Patients with polypharmacy i.e. $>7$ all prescribed drugs or $\geq 3$ anticancer drugs had a significantly increased risk of pDDIs. Whereas, list of most frequently identified major and moderate interactions will aid in timely identification, prevention and management of 
pDDIs and their adverse outcome in cancer patients. Moreover, strict patient monitoring is recommended especially in patients with $>7$ all prescribed drugs or $\geq 3$ anticancer drugs for timely prevention and/or management of negative clinical outcomes associated with these interactions particularly those involving cytotoxic drugs.

\section{Abbreviations}

Cl: Confidence interval; DDIs: Drug-drug interactions; HMC: Hayatabad medical complex; NWGH \& RC:

Northwest General Hospital and Research Center; OR: Odds ratios; pDDIs: potential drug-drug interactions.

\section{Declarations}

\section{Ethics approval and consent to participate}

Ethical approval was obtained from the Ethical Committee of Department of Pharmacy, University of Peshawar, Khyber Pakhtunkhwa, Pakistan. This was a retrospective study, involving data collected from the hospitals, therefore individual informed consent was not applicable.

\section{Consent for publication}

Not applicable

\section{Availability of data and material}

The datasets used and/or analyzed during the current study are available from the corresponding author on reasonable request.

\section{Competing interests}

The authors declare that they have no competing interests.

\section{Funding}

No funding has been taken for this study.

\section{Authors' contributions}

All the authors contributed substantially to the work presented in this paper, read and approved the final version of manuscript. MI designed the research, contributed substantially with data analysis, results interpretations and manuscript editing and approval. SK designed all the work under the supervision of Ml, collected, analyzed and interpreted data, did DDIs screening, drafted the manuscript. FK and SN collected, analyzed and interpreted data, did DDIs screening and drafted the manuscript. HS, SY, and IR collected and analyzed data, interpreted results, did DDIs screening and drafted the manuscript.

\section{Acknowledgements}

We are very thankful for the cooperation of staff and administration of the hospitals. 


\section{References}

1. Jemal A, Bray F, Center MM, Ferlay J, Ward E, Forman D. Global cancer statistics. CA Cancer J Clin. 2011;61:69-90.

2. Cancer. http://www.who.int/mediacentre/factsheets/fs297/en/accessed Accessed 9 March 2016.

3. Torre LA, Bray F, Siegel RL, Ferlay J, Lortet-Tieulent J, Jemal A. Global cancer statistics, 2012. CA Cancer J Clin. 2015;65:87-108.

4. Park S, Bae J, Nam BH, Yoo KY. Aetiology of cancer in Asia. Asian Pac J Cancer Prev. 2008;9:371-80.

5. Ferlay J, Shin HR, Bray F, Forman D, Mathers C, Parkin DM. Estimates of worldwide burden of cancer in 2008: GLOBOCAN 2008. Int J Cancer. 2010;127:2893-917.

6. Estimated Cancer Incidence, Mortality and Prevalence Worlwide in 2012, Available at http://globocan.iarc.fr/Default.aspxAccessed Accessed on 9 March, 2016.

7. Siegel R, DeSantis C, Virgo K, Stein K, Mariotto A, Smith T, et al. Cancer treatment and survivorship statistics, 2012. CA Cancer J Clin. 2012;62:220-41.

8. Cancer Treatment Types, American Cancer Society. http://www.cancer.org/treatment/treatmentsandsideeffects/treatmenttypes/ Accessed 11 March 2016.

9. Cancer Treatment Types, Cancer Research UK. http://www.cancerresearchuk.org/about-cancer/cancers-ingeneral/treatment/ Accessed 11 March 2016.

10. Nussbaumer S, Bonnabry P, Veuthey JL, Fleury-Souverain S. Analysis of anticancer drugs: a review. Talanta. 2011;85:2265-89.

11. Chemotherapy, American Cancer Society. http://www.cancer.org/treatment/treatmentsandsideeffects/treatmenttypes/chemotherapy/chemotherapylanding. Accessed 30 May 2016.

12. Bardelmeijer HA, van Tellingen $\mathrm{O}$, Schellens $\mathrm{JH}$, Beijnen $\mathrm{JH}$. The oral route for the administration of cytotoxic drugs: strategies to increase the efficiency and consistency of drug delivery. Invest New Drugs. 2000;18:231-41.

13. Cagnoni PJ, Matthes S, Day TC, Bearman SI, Shpall EJ, Jones RB. Modification of the pharmacokinetics of high-dose cyclophosphamide and cisplatin by antiemetics. Bone Marrow Transplant. 1999;24:1-4.

14. Dechanont S, Maphanta S, Butthum B, Kongkaew C. Hospital admissions/visits associated with drug-drug interactions: a systematic review and meta-analysis. Pharmacoepidemiol Drug Saf. 2014;23:489-97.

15. Zwart-van Rijkom JE, Uijtendaal EV, ten Berg MJ, van Solinge WW, Egberts AC. Frequency and nature of drug-drug interactions in a Dutch university hospital. Br J Clin Pharmacol. 2009;68:187-93.

16. Reimche L, Forster AJ, van Walraven C. Incidence and contributors to potential drug-drug interactions in hospitalized patients. J Clin Pharmacol. 2011;51:1043-50.

17. Stoll P, Kopittke L. Potential drug-drug interactions in hospitalized patients undergoing systemic chemotherapy: a prospective cohort study. Int J Clin Pharm. 2015;37:475-84.

18. Gagne JJ, Maio V, Rabinowitz C. Prevalence and predictors of potential drug-drug interactions in Regione Emilia-Romagna, Italy. J Clin Pharm Ther. 2008;33:141-51. 
19. Miranda V, Fede A, Nobuo M, Ayres V, Giglio A, Miranda M, et al. Adverse drug reactions and drug interactions as causes of hospital admission in oncology. J Pain Symptom Manage. 2011;42:342-53.

20. Del Giglio A, Miranda V, Fede A, Nobuo M, Miranda M, Ayres V, et al. Adverse drug reactions and drug interactions as causes of hospital admission in oncology. ASCO Annual Meeting Proceedings. 2009;27:e20656.

21. Buajordet I, Ebbesen J, Erikssen J, Brors O, Hilberg T. Fatal adverse drug events: the paradox of drug treatment. J Intern Med. 2001;250:327-41.

22. Janchawee B, Wongpoowarak W, Owatranporn T, Chongsuvivatwong V. Pharmacoepidemiologic study of potential drug interactions in outpatients of a university hospital in Thailand. J Clin Pharm Ther. 2005;30:13-20.

23. Cruciol-Souza JM, Thomson JC. A pharmacoepidemiologic study of drug interactions in a Brazilian teaching hospital. Clinics (Sao Paulo). 2006;61:515-20.

24. van Leeuwen RW, Jansman FG, van den Bemt PM, de Man F, Piran F, Vincenten I, et al. Drug-drug interactions in patients treated for cancer: a prospective study on clinical interventions. Ann Oncol. 2015;26:992-7.

25. Ismail M, Iqbal Z, Khattak MB, Khan MI, Arsalan H, Javaid A, et al. Potential drug-drug interactions in internal medicine wards in hospital setting in Pakistan. Int J Clin Pharm. 2013;35:455-62.

26. Popa MA, Wallace KJ, Brunello A, Extermann M, Balducci L. Potential drug interactions and chemotoxicity in older patients with cancer receiving chemotherapy. J Geriatr Oncol. 2014;5:307-14.

27. Riechelmann RP, Moreira F, Smaletz O, Saad ED. Potential for drug interactions in hospitalized cancer patients. Cancer Chemother Pharmacol. 2005;56:286-90.

28. Ko Y, Tan SL, Chan A, Wong YP, Yong WP, Ng RC, et al. Prevalence of the coprescription of clinically important interacting drug combinations involving oral anticancer agents in Singapore: a retrospective database study. Clin Ther. 2012;34:1696-704.

29. Chen L, Cheung WY. Potential drug interactions in patients with a history of cancer. Curr Oncol. 2014;21:e212-20.

30. Khan Q, Ismail M, Haider I, Haq IU, Noor S. QT interval prolongation in hospitalized patients on cardiology wards: a prospective observational study. Eur J Clin Pharmacol. 2017;73:1511-8.

31. Pervaiz F, Khan MZ, Azhar S, Hussain A, Masood J, Zaib-Un-Nisa, et al. Prevalence of Potential Drug-Drug Interactions in Cancer Patients at Cancer Hospitals in Pakistan. LATIN AMERICAN JOURNAL OF PHARMACY. 2014;33:1159-66.

32. Azim M, Khan A, Khan TM, Kamran M. A cross-sectional study: medication safety among cancer inpatients in tertiary care hospitals in KPK, Pakistan. BMC Health Serv Res. 2019;19:583.

33. van Oijen B, Janknegt R, de Wit H, Peters F, Schouten $H$, van der Kuy $H$. Medication surveillance on intravenous cytotoxic agents: a retrospective study. Int J Clin Pharm. 2013;35:554-9.

34. Lopez-Martin C, Garrido Siles M, Alcaide-Garcia J, Faus Felipe V. Role of clinical pharmacists to prevent drug interactions in cancer outpatients: a single-centre experience. Int J Clin Pharm. 2014;36:1251-9.

35. Abarca J, Colon LR, Wang VS, Malone DC, Murphy JE, Armstrong EP. Evaluation of the performance of drug-drug interaction screening software in community and hospital pharmacies. J Manag Care Pharm. 2006;12:383-9. 
36. Micromedex Drug-Reax®, Truven Health Analytics. http://www.micromedexsolutions.com/home/dispatch. Accessed September 2015.

37. Patel RI, Beckett RD. Evaluation of resources for analyzing drug interactions. J Med Libr Assoc. 2016;104:290-5.

38. Kheshti R, Aalipour M, Namazi S. A comparison of five common drug-drug interaction software programs regarding accuracy and comprehensiveness. J Res Pharm Pract. 2016;5:257-63.

39. Bossaer JB, Thomas CM. Drug interaction database sensitivity with oral antineoplastics: An exploratory analysis. Journal of oncology practice. 2017;13:e217-e22.

40. Hadjibabaie M, Badri S, Ataei S, Moslehi AH, Karimzadeh I, Ghavamzadeh A. Potential drug-drug interactions at a referral hematology-oncology ward in Iran: a cross-sectional study. Cancer Chemother Pharmacol. 2013;71:1619-27.

41. van Leeuwen RW, Brundel DH, Neef C, van Gelder T, Mathijssen RH, Burger DM, et al. Prevalence of potential drug-drug interactions in cancer patients treated with oral anticancer drugs. Br J Cancer. 2013;108:1071-8.

42. Ismail M, Iqbal Z, Khattak MB, Javaid A, Khan MI, Khan TM, et al. Potential drug-drug interactions in psychiatric ward of a tertiary care hospital: prevalence, levels and association with risk factors. Trop $\mathrm{J}$ Pharm Res. 2012;11:289-96.

43. Ismail M, Iqbal Z, Khan MI, Javaid A, Arsalan H, Farhadullah H, et al. Frequency, Levels and Predictors of Potential Drug-Drug Interactions in a Pediatrics Ward of a Teaching Hospital in Pakistan. Trop J Pharm Res. 2013;12:401-6.

44. Ismail M, Iqbal Z, Khattak MB, Javaid A, Khan TM. Prevalence, types and predictors of potential drug-drug interactions in pulmonology ward of a tertiary care hospital. Afr J Pharm Pharmacol. 2011;5:1303-9.

45. Riechelmann RP, Tannock IF, Wang L, Saad ED, Taback NA, Krzyzanowska MK. Potential drug interactions and duplicate prescriptions among cancer patients. J Natl Cancer Inst. 2007;99:592-600.

46. Van Leeuwen R, Swart E, Boven E, Boom F, Schuitenmaker M, Hugtenburg J. Potential drug interactions in cancer therapy: a prevalence study using an advanced screening method. Ann Oncol. 2011;22:2334-41.

47. Doubova VS, Reyes-Morales H, del PilarTorres-Arreola L, Suárez-Ortega M. Potential drug-drug and drugdisease interactions in prescriptions for ambulatory patients over 50 years of age in family medicine clinics in Mexico City. BMC Health Serv Res. 2007;7:1.

48. Riechelmann RP, Zimmermann C, Chin SN, Wang L, O'Carroll A, Zarinehbaf S, et al. Potential drug interactions in cancer patients receiving supportive care exclusively. J Pain Symptom Manage. 2008;35:535-43.

49. Tavakoli Ardakani M, Kazemian K, Salamzadeh J, Mehdizadeh M. Potential of drug interactions among hospitalized cancer patients in a developing country. Iran J Pharm Res. 2013;12:175-82

\section{Tables}

Table 1 Patient characteristics $(\mathrm{N}=678)$ 


\begin{tabular}{ll}
\hline Variables & Patients: $\mathbf{n}$ (\%) \\
\hline Gender & $358(52.8)$ \\
Male & $320(47.2)$ \\
\hline Female & \\
\hline Age (years) & $101(14.9)$ \\
$\leq 10$ & $110(16.2)$ \\
\hline $11-20$ & $179(26.4)$ \\
\hline $21-40$ & $200(29.5)$ \\
\hline $41-60$ & $88(13)$ \\
\hline$>60$ & \\
\hline All prescribed drugs & $120(17.7)$ \\
\hline$\leq 6$ & $253(37.3)$ \\
\hline $7-9$ & $199(29.4)$ \\
\hline $10-12$ & $64(9.4)$ \\
\hline $13-15$ & $42(6.2)$ \\
\hline$>15$ & \\
\hline Anticancer drugs & $123(18.1)$ \\
\hline 1 & $264(38.9)$ \\
\hline 2 & $159(23.5)$ \\
\hline 3 & $132(19.5)$ \\
\hline$\geq 4$ & $84(12.4)$ \\
\hline Supportive care drugs & $242(35.7)$ \\
\hline$\leq 3$ & $246(36.3)$ \\
\hline $4-6$ & $106(15.6)$ \\
\hline $7-9$ &
\end{tabular}

Table 2 Cancer characteristics and their types 


\begin{tabular}{ll}
\hline Variables & Patients: $\mathbf{n}(\%)$ \\
\hline $\begin{array}{l}\text { Cancer type } \\
\text { Solid malignancy }\end{array}$ & $360(53.1)$ \\
\hline Hematologic cancer & $318(46.9)$ \\
\hline Metastasis & $112(16.5)$ \\
\hline Present & $566(83.5)$ \\
\hline Absent & \\
\hline Treatment intent & $620(91.4)$ \\
\hline Curative & $58(8.6)$ \\
\hline Palliative & \\
\hline Type of chemotherapy & $508(74.9)$ \\
\hline Cytotoxic agents & $4(0.6)$ \\
\hline Hormonal agents & $3(0.4)$ \\
\hline Monoclonal agents & $163(24)$ \\
\hline Combination* & \\
\hline Solid malignancy & $89(13.1)$ \\
\hline Gastrointestinal cancer & $64(9.4)$ \\
\hline Breast cancer & $47(6.9)$ \\
\hline Gynecological cancer & $42(6.2)$ \\
\hline Musculoskeletal cancer & $41(6)$ \\
\hline Genitourinary cancer & $19(2.8)$ \\
\hline Head and neck cancer & $13(1.9)$ \\
\hline Neurological cancer & $11(1.6)$ \\
\hline Respiratory cancer & $34(5)$ \\
\hline Others & $127(18.7)$ \\
\hline Hematological malignancy & $117(17.3)$ \\
\hline Acute lymphoblastic leukemia & $28(4.1)$ \\
\hline Non-Hodgkin lymphoma & $17(2.5)$ \\
\hline Acute myelogenous leukemia & $18(2.5)$ \\
\hline Chronic lymphocytic leukemia & \\
\hline Hodgkin lymphoma & $(1)$ \\
\hline Chronic myelogenous leukemia & \\
\hline Others & \\
\hline & \\
\hline
\end{tabular}

-*Combination means regimen comprising of cytotoxic, hormonal or monoclonal agents in combination.

Table 3 Univariate and multivariate logistic regression analysis 


\begin{tabular}{|c|c|c|c|c|}
\hline \multirow[t]{2}{*}{ Variables } & \multicolumn{2}{|l|}{ Univariate } & \multicolumn{2}{|l|}{ Multivariate } \\
\hline & OR $(95 \% \mathrm{CI})$ & p-value & OR $(95 \% \mathrm{CI})$ & p-value \\
\hline \multicolumn{5}{|l|}{ Gender } \\
\hline Male & Reference & & - & \\
\hline Female & $0.7(0.5-1)$ & 0.108 & - & - \\
\hline \multicolumn{5}{|l|}{ Age (years) } \\
\hline$\leq 50$ & Reference & & - & \\
\hline$>50$ & $0.8(0.5-1.2)$ & 0.318 & - & - \\
\hline \multicolumn{5}{|l|}{ All drugs prescribed } \\
\hline$\leq 7$ & Reference & & Reference & \\
\hline$>7$ & $3.6(2.5-5.3)$ & 0.0001 & $3.5(2.2-5.5)$ & 0.0001 \\
\hline \multicolumn{5}{|l|}{ Anticancer drugs } \\
\hline$\leq 2$ & Reference & & Reference & \\
\hline$\geq 3$ & $4.7(3-7.4)$ & 0.0001 & $3.6(2.1-6.2)$ & 0.0001 \\
\hline \multicolumn{5}{|l|}{ Supportive care drugs } \\
\hline$\leq 3$ & Reference & & Reference & \\
\hline$>3$ & $1.9(1.3-2.9)$ & 0.001 & $0.6(0.3-1.2)$ & 0.161 \\
\hline \multicolumn{5}{|l|}{ Hospitalization status } \\
\hline Ambulatory & Reference & & Reference & \\
\hline Hospitalized & $1.8(1.2-2.6)$ & 0.004 & $1.3(0.8-2)$ & 0.327 \\
\hline \multicolumn{5}{|l|}{ Cancer type } \\
\hline Hematological malignancy & Reference & & Reference & \\
\hline Solid malignancy & $0.4(0.3-0.6)$ & 0.0001 & $0.7(0.4-1.1)$ & 0.173 \\
\hline \multicolumn{5}{|l|}{ Metastasis } \\
\hline Present & Reference & & - & \\
\hline Absent & $1.5(0.9-2.4)$ & 0.07 & - & - \\
\hline \multicolumn{5}{|l|}{ Treatment type } \\
\hline Cytotoxic agents & Reference & & Reference & \\
\hline Combination drugs* & $2.1(1.3-3.4)$ & 0.003 & $0.7(0.4-1.3)$ & 0.343 \\
\hline \multicolumn{5}{|l|}{ Treatment intent } \\
\hline Curative & Reference & & - & \\
\hline Palliative & $1.6(0.8-3.3)$ & 0.218 & - & - \\
\hline
\end{tabular}

- pDDIs = potential drug-drug interactions; $\mathrm{OR}=$ odds ratio; $\mathrm{CI}=$ confidence interval.

-Hosmer-Lemeshow goodness-of-fit test: $\mathrm{p}=0.3$

-*Combination means regimen comprising of cytotoxic, hormonal or monoclonal agents in combination.

Table 4 Abnormal biochemical results and symptoms among study subjects 


\begin{tabular}{|c|c|}
\hline Laboratory test & Patients: $\mathrm{n}$ \\
\hline \multicolumn{2}{|l|}{ Hematological tests } \\
\hline \multicolumn{2}{|l|}{ Hemoglobin } \\
\hline$<12 \mathrm{~g} / \mathrm{dL}$ & $398(58.7)$ \\
\hline \multicolumn{2}{|l|}{ Red blood cells } \\
\hline$<4 \times 106 / \mathrm{mm} 3$ & $118(17.4)$ \\
\hline$>5.5 \times 106 / \mathrm{mm} 3$ & $11(1.6)$ \\
\hline \multicolumn{2}{|l|}{ Total leukocyte count } \\
\hline$<4000 / \mathrm{mm} 3$ & $96(14.2)$ \\
\hline$>11000 / \mathrm{mm} 3$ & $145(21.4)$ \\
\hline \multicolumn{2}{|l|}{ Platelet count } \\
\hline$<150000 / \mathrm{mm} 3$ & $138(20.4)$ \\
\hline$>450000 / \mathrm{mm} 3$ & $63(9.3)$ \\
\hline \multicolumn{2}{|l|}{ Neutrophils } \\
\hline$<40 \%$ & $70(10.3)$ \\
\hline$>75 \%$ & $113(16.7)$ \\
\hline \multicolumn{2}{|l|}{ Lymphocytes } \\
\hline$<20 \%$ & $149(21.9)$ \\
\hline$>45 \%$ & $91(13.4)$ \\
\hline \multicolumn{2}{|l|}{ Eosinophils } \\
\hline$<1 \%$ & $47(6.9)$ \\
\hline$>6 \%$ & $17(2.5)$ \\
\hline \multicolumn{2}{|l|}{ Monocytes } \\
\hline$<6 \%$ & $372(54.9)$ \\
\hline$>10 \%$ & $23(3.4)$ \\
\hline \multicolumn{2}{|l|}{ Renal function tests } \\
\hline \multicolumn{2}{|l|}{ Serum creatinine } \\
\hline$>1.3 \mathrm{mg} / \mathrm{dl}$ & $26(3.8)$ \\
\hline $\begin{array}{l}\text { Total bilirubin } \\
>1.5 \mathrm{mg} / \mathrm{dl}\end{array}$ & $12(1.8)$ \\
\hline \multicolumn{2}{|l|}{ Liver function tests } \\
\hline \multicolumn{2}{|l|}{ Alanine aminotransferase } \\
\hline$>40 \mathrm{U} / \mathrm{L}$ & $121(17.8)$ \\
\hline \multicolumn{2}{|l|}{ Aspartate aminotransferase } \\
\hline$>40 \mathrm{U} / \mathrm{L}$ & $46(6.8)$ \\
\hline \multicolumn{2}{|l|}{ Alkaline phosphatase } \\
\hline$<35 \mathrm{U} / \mathrm{L}$ & $3(0.4)$ \\
\hline$>130 \mathrm{U} / \mathrm{L}$ & $106(15.6)$ \\
\hline \multicolumn{2}{|l|}{ Symptoms } \\
\hline Fever & $82(12.1)$ \\
\hline Generalized body aches & $63(9.3)$ \\
\hline Nausea and vomiting & $32(4.7)$ \\
\hline Abdominal pain & $28(4.1)$ \\
\hline Cough & $26(3.8)$ \\
\hline Anorexia & $19(2.8)$ \\
\hline Shortness of breath & $15(2.2)$ \\
\hline Generalized weakness & $11(1.6)$ \\
\hline Pallor & $11(1.6)$ \\
\hline Swelling in different body parts & $10(1.5)$ \\
\hline
\end{tabular}


Bleeding from different body parts

Loose motions

Abdominal distension

Epigastric pain

Dysphagia

Sweating

Urinary tract infections
9 (1.3)

$10(1.3)$

$8(1.2)$

$9(1.2)$

$10(1.2)$

$11(1.2)$

$12(1.2)$

Table 5 Most frequent pDDIs among cancer patients

\section{Figures}

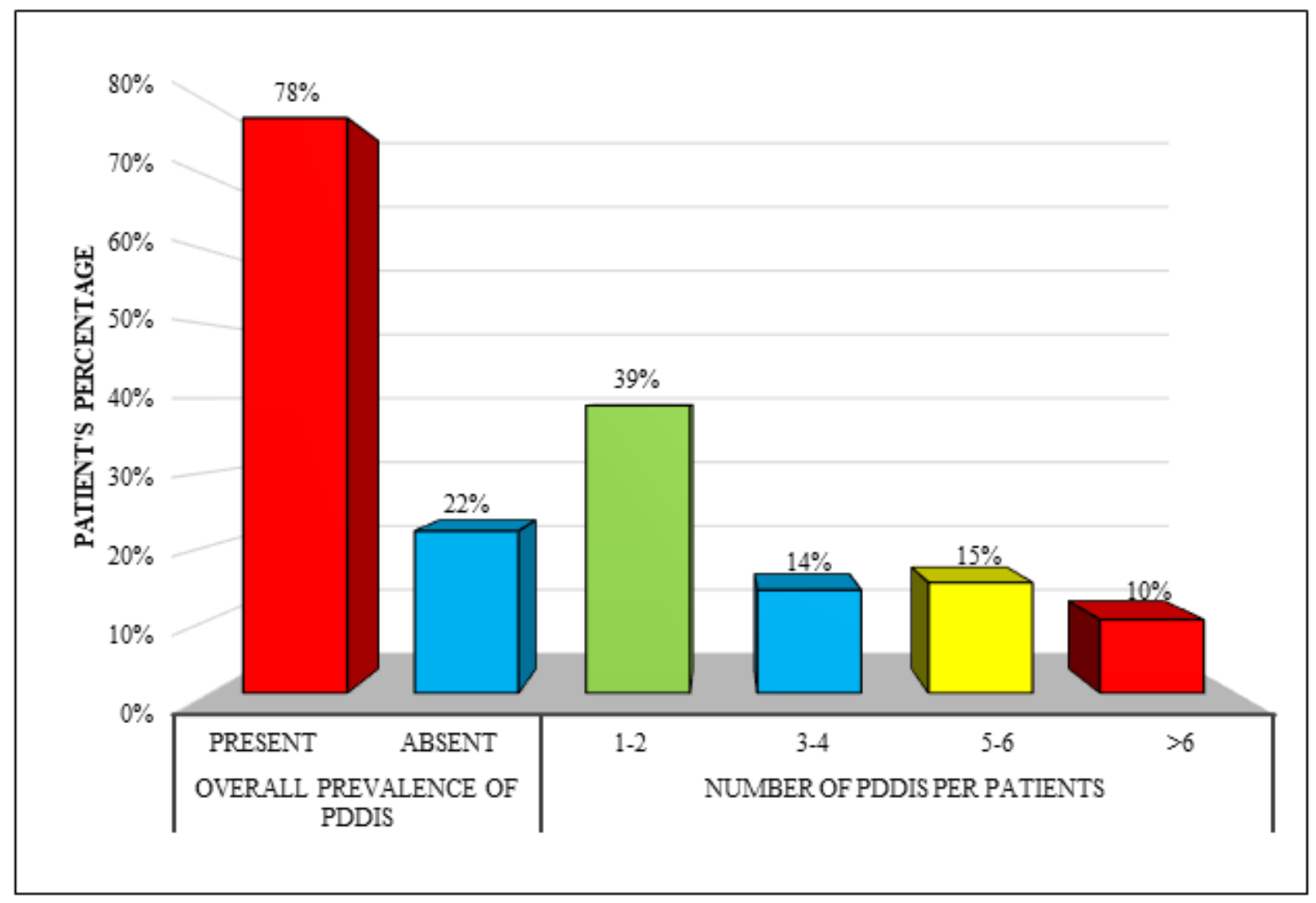

Figure 1

Prevalence of pDDIs $-\mathrm{PDDIs}=$ potential drug-drug interactions - Overall prevalence means occurrence of pDDIs regardless of severity. -Percentages do not add up to $78 \%$ because many patients were exposed to multiple pDDIs of different severities 


\begin{tabular}{|c|c|c|c|c|}
\hline $\begin{array}{l}\text { Drug-drug } \\
\text { interaction }\end{array}$ & Frequency & Severity & Evidence & Potential adverse outcome \\
\hline $\begin{array}{l}\text { Dexamethasone }+ \\
\text { Vincristine }\end{array}$ & 228 & Major & Fair & Decreased vincristine plasma concentration. \\
\hline $\begin{array}{l}\text { Doxorubicin }+ \\
\text { Dexamethasone }\end{array}$ & 164 & Major & Fair & Reduced doxorubicin exposure. \\
\hline $\begin{array}{l}\text { Ondansetron }+ \\
\text { Prochlorperazine }\end{array}$ & 116 & Major & Fair & Increased risk of QT interval prolongation. \\
\hline $\begin{array}{l}\text { Cyclophosphamide } \\
+ \text { Doxorubicin }\end{array}$ & 105 & Major & Fair & High risk of cardiomyopathy. \\
\hline $\begin{array}{l}\text { Ciprofloxacin }+ \\
\text { Dexamethasone }\end{array}$ & 102 & Moderate & Excellent & Increased risk for tendon rupture. \\
\hline $\begin{array}{l}\text { Ciprofloxacin }+ \\
\text { Ondansetron }\end{array}$ & 89 & Major & Fair & Increased risk of QT interval prolongation. \\
\hline $\begin{array}{l}\text { Ciprofloxacin }+ \\
\text { Prochlorperazine }\end{array}$ & 83 & Major & Fair & Increased risk of QT interval prolongation. \\
\hline $\begin{array}{l}\text { Cyclophosphamide } \\
+ \text { Ondansetron }\end{array}$ & 75 & Moderate & Good & Decreased cyclophosphamide systemic exposure. \\
\hline $\begin{array}{l}\text { Allopurinol }+ \\
\text { Cyclophosphamide }\end{array}$ & 66 & Major & Good & $\begin{array}{l}\text { Cyclophosphamide toxicity (bone marrow suppression, nausea, } \\
\text { vomiting). }\end{array}$ \\
\hline $\begin{array}{l}\text { Metoclopramide }+ \\
\text { Tramadol }\end{array}$ & 48 & Major & Fair & Increased risk of seizures. \\
\hline $\begin{array}{l}\text { Ciprofloxacin }+ \\
\text { Doxorubicin }\end{array}$ & 33 & Major & Fair & Increased doxorubicin exposure. \\
\hline $\begin{array}{l}\text { Calcium Chloride } \\
+ \text { Ciprofloxacin }\end{array}$ & 32 & Moderate & Good & Decreased ciprofloxacin efficacy. \\
\hline $\begin{array}{l}\text { Ondansetron }+ \\
\text { Tramadol }\end{array}$ & 31 & Moderate & Excellent & Reduced efficacy of tramadol. \\
\hline $\begin{array}{l}\text { Tropisetron }+ \\
\text { Tramadol }\end{array}$ & 24 & Major & Fair & Increased risk of serotonin syndrome. \\
\hline $\begin{array}{l}\text { Fluorouracil }+ \\
\text { Leucovorin }\end{array}$ & 23 & Moderate & Good & $\begin{array}{l}\text { Increased concentrations of 5-fluorouracil and fluorouracil } \\
\text { toxicity (granulocytopenia, anemia, thrombocytopenia, } \\
\text { stomatitis, vomiting). }\end{array}$ \\
\hline $\begin{array}{l}\text { Asparaginase }+ \\
\text { Vincristine }\end{array}$ & 19 & Major & Fair & Increased vincristine exposure causing neurotoxicity. \\
\hline $\begin{array}{l}\text { Cisplatin }+ \\
\text { Docetaxel }\end{array}$ & 14 & Moderate & Excellent & Increased risk of neuropathy. \\
\hline $\begin{array}{l}\text { Methotrexate }+ \\
\text { Omeprazole }\end{array}$ & 13 & Major & Good & $\begin{array}{l}\text { Increased concentration of methotrexate and its metabolite } \\
\text { and an increased risk of methotrexate toxicity. }\end{array}$ \\
\hline $\begin{array}{l}\text { Cisplatin }+ \\
\text { Doxorubicin }\end{array}$ & 11 & Major & Good & $\begin{array}{l}\text { Increased risk of Secondary malignancy i.e. secondary } \\
\text { leukemia. }\end{array}$ \\
\hline $\begin{array}{l}\text { Fluconazole + } \\
\text { Metronidazole }\end{array}$ & 10 & Major & Fair & Increased risk of QT interval prolongation and arrhythmias. \\
\hline
\end{tabular}




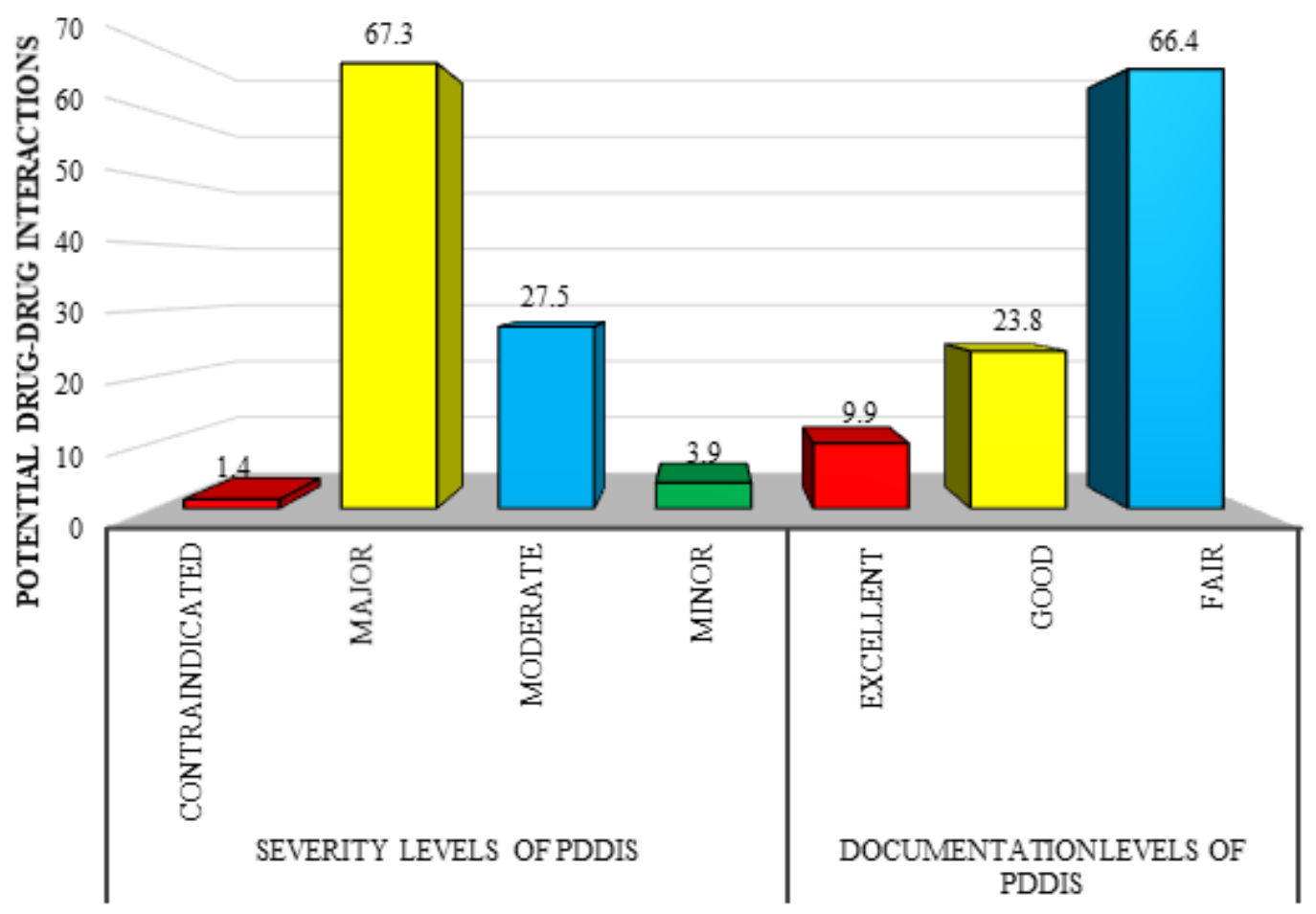

Figure 2

Levels of pDDIs

\section{Supplementary Files}

This is a list of supplementary files associated with this preprint. Click to download.

- STROBEchecklistcrosssectional.doc

- AdditionalTable1.docx 